\title{
Evaluation of the nutritional quality of selected dietary ingredients for mud crab Scylla serrata of Suarashtra region in Gujarat, India
}

\author{
Sumara M. Ayaz K.* \\ Department of Aquaculture, College of Fisheries Science, Junagadh Agricultural University, \\ Veraval-362265 (Gujarat), India \\ K. H. Vadher \\ Department of Aquaculture, College of Fisheries Science, Junagadh Agricultural University, \\ Veraval-362265 (Gujarat), India \\ ${ }^{*}$ Corresponding author. E. mail: sumaraayaz@gmail.com
}

\section{Article Info}

https://doi.org/10.31018/

jans.v12i3.2243

Received: March 16, 2020

Revised: June 27, 2020

Accepted: July 11, 2020

\section{How to Cite}

Ayaz, K. S. M. and Vadher, K.H. (2020). Evaluation of the nutritional quality of selected dietary ingredients for mud crab Scylla serrata of Suarashtra region in Gujarat, India. Journal of Applied and Natural Science, 12(3): 288 - 291. https://doi.org/10.31 018/jans.v12i3.2243

\begin{abstract}
Mud crabs, or mangrove crabs, are one of the most valuable groups of crab species in the world. Several studies have been conducted to describe the nutrient requirements of mud crabs. Only preliminary studies have been conducted to define the nutritional ingredients requirements for growing out diets. Results of the analysis revealed the major components of seaweeds (Ulva reticulate and Sargassum cinctum) poultry waste, earth worms and fish meal with carbohydrate $57.18 \%$ (Ulva reticulate) and $55.86 \%$ (Sargassum cinctum), $31.07 \%, 21.83 \%$ and $2.89 \%$, followed by ash content of $21.3 \%$ (U. reticulate) and $14.1 \%$ (S. cinctum), $8.4 \%, 12.0 \%$ and $8.40 \%$, respectively. The crude protein component of fishmeal, soyabean meal, earthworms and seaweeds were obtained in little amount with $61.20 \%, 48.3 \%, 36.2 \%$ and $13.41 \%$ (U. reticulate) and $10.67 \%$ (S. cinctum) and followed by crude lipid component of poultry waste $25.0 \%$, seaweeds $13.41 \%$ (U. reticulate) and $10.67 \%$ (S. cinctum), earthworms $9.52 \%$ and fishmeal $9.20 \%$ respectively. These results of nutritional composition indicated that poultry waste, earthworms and seaweeds have potential as a source of feed supplement and human nutrition.
\end{abstract}

Keywords: Ingredient, Mud crab, Poultry waste, Sargassum cinctum and Ulva reticulate

\section{INTRODUCTION}

Mud crabs, or mangrove crabs, are one of the most valuable groups of crab species in the world. Mud crab, genus Scylla aquaculture is expected to continue to grow in the future (Azra and Ikhwanuddin, 2016). Production of mud crabs in 2015 was around 226,390 metric tons (Anonymous, 2015) with a farm-gate value of US\$1.06 billion. Commercial markets are primarily driven by live or frozen soft-shell crab sales (Quinitio and Lwin, 2009). Traditionally, mud crabs were viewed as carnivores with preferences in their natural diet for molluscs, crustaceans and fishes that have relatively high protein content (Hill, 1979). Several studies have been conducted to describe the nutrient requirements of mud crabs, and only preliminary studies have been conducted to define the nutritional ingredients requirements for growing out diets.

The raw ingredients that will be selected for feed production must be sustainable, cost-effective and with steady availability. However, the availability of these ingredients is becoming more restricted and the prices are increasing accordingly. Therefore, these ingredients must be spared and replaced by meals from sustainable sources. The alternative sources may include fish meal, poultry waste, earthworms, spirulina, moringa leaf, seaweeds and other dietary feed ingredients. Fish meal, Poultry waste, Earthworms, Spirulina, Moringa leaf, Seaweeds and other dietary feed ingredients are rich in proteins, vitamins, carbohydrates, fibre, lipids, and minerals and are easy to obtain. Some species of algae may contain more protein, carbohydrates, and fat than the ingredients traditionally used in trash fish diets in crab (Catacutan, 2002). The find out of best suitable ingredients for mud crab feed can give new direction in the development of fattening feeds in commercial direction for soft shell mud crab grower. A cost-effective replacement of ingredients is needed to ensure the benefits gained to date are not lost. Therefore, the present study was 
undertaken for evaluation of the nutritional quality of selected dietary ingredients (viz. poultry waste, earthworms, fishmeal,Ulva reticulata and Sargassum cinctum) in the pelleted feed of Scylla serrata.

\section{MATERIALS AND METHODS}

Site of experiment: The experimental analysis was carried out at the Department of Aquaculture, College of Fisheries Science, Junagadh Agricultural University, Veraval (Gujarat), India.

Sample collection: Poultry waste used consisted of wastes including viscera, heads, legs and feather. This poultry waste was collected from local chicken slaughter and was washed thoroughly with tap water in order to remove unwanted parts of chicken was made by exposing to $150-200^{\circ} \mathrm{C}$ with 2.5 bar (atmospheric pressure) for $5 \mathrm{hrs}$. Both poultry wastes and fish meal were tested for nutritional composition for the diet formulation. Fresh marine seaweeds Ulva reticulata and Sargassum cinctum were accumulated from the rocky seashore region of Veraval coast, Saurashtra region of Gujarat. The accumulated seaweeds were washed thoroughly with fresh water in order to remove epiphytes as well as other marine organisms, and then seaweeds fixed on herbarium sheet for the making of voucher specimen and then identified with the help of the standard literature. After that identified seaweeds were dried under shade at room temperature and samples of dried seaweeds were ground well by using a mixer grinder and sieved by a nylon sieve in order to remove seaweed fibre. Fish meal was procured from the fish meal plant at Porbandar. The moringa leaves, earthworms, bloodworms, spirulina, soybean meal and remains all feed ingredients were purchase from Veraval market.

Composition of ingredient analysis: Compositions of samples were analyzed by standard methods of AOAC (Anon., 2000). Crude protein content was analyzed using the Kjeldahl method. Crude lipid was examined with the Soxhlet apparatus. Moisture and ash content were analyzed with the help of the incubator and muffle furnace, respectively.

Crude protein (CP): The protein content of the samples was determined as total nitrogen using micro Kjeldahl method after acid digestion. The nitrogen content of the sample was determined constitutively by using semi-automatic micro-kjeldahl digestion and distillation apparatus (Gerhardt, Germany). Protein percentage was calculated by multiplying the nitrogen percentage found with a factor of 6.25 .

Crude protein $(\%)=\mathrm{N}_{2}$ (nitrogen $\%$ ) $\times 6.25 \quad \ldots .$. Eq. 1

Crude lipid: Crude lipid was estimated by the ether extraction by using Soxhlets apparatus with petroleum ether (Boiling point $40-60^{\circ} \mathrm{C}$ ) as the solvent. The con- tents of crude lipids were determined gravimetrically after oven-drying $\left(80^{\circ} \mathrm{C}\right)$ the extract overnight.

$$
\text { Crude lipid }(\%)=\frac{\text { Weight of the ether extract }}{\text { Sample Weight }} \times 100
$$

Moisture: Moisture content was estimated by taking a known weight of samples in petri-dish for oven-drying at $100-105^{\circ} \mathrm{C}$ till a constant weight was achieved. After the process, weight loss in samples was calculated as moisture content, which was calculated by using the following

formula.

$$
\text { Moisture }(\%)=\frac{\text { Wet weight of sample-Dried weight of sample }}{\text { Wet weight of sample }} \times 100
$$

Ash: Ash content was determined by taking a known weight of sample in silica crucible and placing it in a muffle furnace at $600^{\circ} \mathrm{C}$ for $6 \mathrm{hrs}$. The calculation was done as follows:

Ash $(\%)=\frac{\text { Weight of Ash }}{\text { Sample Weight }} \times 100$

Total carbohydrate: Total carbohydrate was estimated by the difference method given by the formula:

Total carbohydrate $=100-(\mathrm{CP}+\mathrm{CL}+$ Moisture + Ash $)$ ......Eq. 5

Analysis of data: Compositions of ingredients were analyzed using standard methods of AOAC (Anon., 2000) and the data obtained in the present investigation were subjected to analysis using Microsoft Excel.

\section{RESULTS AND DISCUSSION}

The proximate composition of selected major ingredients viz, poultry waste, earthworms, fishmeal, seaweeds species $U$. reticulata and $S$. cinctum meal, as well as other diet ingredient soybean meal, moringa leaf, tubifex worms, fermented silage and blood worms, are shown in Table 1.

Results of the analysis revealed that the major components of seaweeds, poultry waste, earth worms and fish meal were the carbohydrate $57.18 \%$ ( U. reticulate) and $55.86 \%$ (Sargassum cinctum), $31.07 \%$, $21.83 \%$ and $2.89 \%$, followed by ash content of 21.3 $\%$ (U. reticulate) and $14.1 \%$ (Sargassum cinctum), $8.4 \%, 12.0 \%$ and $8.40 \%$, respectively. Crude protein component of fishmeal, soyabean meal, earthworms and seaweeds were obtained in amount with $61.20 \%$, $48.3 \%, 36.2 \%$ and $13.41 \%$ (U. reticulate) and $10.67 \%$ (Sargassum cinctum) and followed by crude lipid component of poultry waste $25.0 \%$, seaweeds $13.41 \%$ (U. reticulate) and $10.67 \%$ (Sargassum cinctum), earthworms $9.52 \%$ and fishmeal $9.20 \%$ respectively. Several studies showed that crabs were able to digest many different ingredients, in particular protein from plants (Catacutanet al., 2003; Truong et al., 2009; Nguyen et al., 2014). Based studies on 
Ayaz, K. S. M. and Vadher, K.H. / J. Appl. \& Nat. Sci. 12(3): 288 - 291 (2020)

Table 1. Composition of ingredients for mud crab diet.

\begin{tabular}{|c|c|c|c|c|c|}
\hline Ingredients (\%) & Moisture & Crude Protein & Crude Lipid & Ash & Carbohydrate \\
\hline Poultry waste & 4.91 & 18.00 & 25.00 & 8.40 & 31.07 \\
\hline Earth worms & 9.20 & 36.2 & 9.52 & 12.0 & 21.83 \\
\hline Fish meal & 6.80 & 61.20 & 9.20 & 8.40 & 2.89 \\
\hline Ulva reticulate & 7.03 & 13.41 & 13.10 & 14.1 & 57.18 \\
\hline Sargassum cinctum & 7.19 & 10.67 & 11.0 & 14.1 & 55.86 \\
\hline Soybean meal & 6.12 & 48.3 & 7.90 & 21.3 & 27.39 \\
\hline Moringa Leaf & 5.90 & 24.55 & 2.48 & 6.52 & 10.03 \\
\hline Fermented Silage & 6.03 & 28.3 & 8.73 & 14.1 & 10.9 \\
\hline Tubifex worms & 5.18 & 52.0 & 8.01 & 3.10 & 13.21 \\
\hline Blood worms & 5.70 & 52.6 & 7.90 & 2.89 & 12.40 \\
\hline
\end{tabular}

protein and lipid (energy) levels and ratios for different levels of shrimp farming provide a guide for crab farming (Alava et al., 2007; Ali et al., 2011; Catacutan et al., 2003; Sheen, 2000).

In the present study, protein and lipid were found to have wide ranges in ingredients which were exhibited in a similar requirement for mud crab formulation diets. Moisture level of earthworms, seaweeds, fish meal and soyabean meal was $9.20 \%, 7.19 \%$ ( $S$. cinctum) and $7.03 \%$ (U. reticulata), $6.80 \%$ and $6.12 \%$. The other component of blood worms, tubifex worms, fermented silage and moringa leaf, were crude protein with $52.6 \%, 52.0 \%, 28.3 \%$ and $24.5 \%$ respectively. In soybean meal levels of carbohydrate $(27.39 \%)$, crude lipid $(7.90 \%)$, ash $(21.3 \%)$ and moisture $(6.12 \%)$ were exhibited while in the fish meal; ash $(8.40 \%)$, crude lipid $(9.20 \%)$, moisture $(6.90 \%)$ and little amount of carbohydrate $(2.89 \%)$ were exhibited. Researchers in the Philippines, Vietnam and Australia reported that crabs have protein requirements of 35$55 \%$ based on their age and size (Catacuanet al., 2002; Tuan et al., 2006; Truong, 2008; Truong et al., 2009; Anderson et al., 2004; Holme et al., 2006).In general, crabs are viewed as carnivores on the basis of gut analyses and feeding observations that contained relatively high protein content (Hill, 1979). Dietary protein supply is one of the major factors that influence the productivity of mud crab species (Davis et al., 2004). The present study showed the per cent level of crude protein and crude lipid found in fishmeal, soyabean meal, poultry waste, earthworms, blood worms, tubifex worms, moringa leaf and seaweeds ( $U$. reticulata and $S$. cinctum) that might be used as ingredients in a formulated crab diet. The availability and quality of these ingredients are good, and they are suitable for the aqua-feed industry. These are also widely used ingredients in aquaculture diets as they have good nutrient profiles, are readily digested by crustacean and are cost-effective when compared other ingredients. Therefore, results indicated that selected ingredients could be considered as an alternative source for feed supplement and animal nutrition.

\section{Conclusion}

In the present investigation, the ingredients like poultry waste, earthworms, and seaweeds contained relatively little amount of protein and lipid compared to that in fishmeal but in optimum range than those found in other seaweed species. The results of the present study demonstrated that mud crabs would accept formulated feeds using targeting ingredients in laboratory process or commercial extrusion. Hence, the development of selected ingredients diets for crabs is technically possible.

\section{ACKNOWLEDGEMENTS}

The first author thankfully acknowledges the ever willing and sincere help giving by the authorities of College of Fisheries Science, Junagadh Agricultural University, Veraval (Gujarat) for giving the permission to pursue postgraduate course of studies for providing all the necessary facilities right from the beginning of the work.

\section{REFERENCES}

1. Anonymous (2000). Official Methods of Analysis of Association of Analytical Chemist (AOAC), Horwitz, W., Gaithersburg, Maryland, USA.

2. Alava, V. R.; Quinitio, E. T.; De Pedro, J. B.; Priolo, F. M. P.; Orozco, Z. G. A. and Wille, M. (2007). Lipids and fatty acids in wild and pond-reared mud crab Scylla serrata (Forsskål) during ovarian maturation and spawning. Aquaculture Research. 38: 1468-1477.

3. Ali, S. A.; Dayal, J. S. and Ambasankar, K. (2011). Presentation and evaluation of formulated feed for mud crab Scylla serrata. Indian Journal of Fisheries.58 (2): 67-73.

4. Anderson, A. J.; Mather, P. B. and Richardson, N.A. (2004). Nutrition of Mud Crab, Scyllaserrata. In: Allan, G. and Fielder, D. eds. Mud Crab Aquaculture in Australia and Southeast Asia. Proceeding of the ACIAR Crab Aquaculture Scoping Study and Workshop, working paper No. 54, ACIAR, pp.57-61.

5. Azra, M. N. and Ikhwanuddin, M. (2016). A review of mat- 
uration diets for mud crab genus Scylla broodstock: Present research, problems and future perspective. Saudi Journal of Biological Sciences, 23 (2): 257-267.

6. Catacutan, M. R. (2002). Growth and body composition of juvenile mud crab, Scylla serrata, fed different dietary protein and lipid levels and protein to energy ratios. Aquaculture,208 (1-2): 113-123.

7. Catacutan, M. R.; Eusebio, P. S. and Teshima, S. 2003. Apparent digestibility of selected feed stuffs by mud crab, Scylla serrata. Aquaculture, 216:253-261.

8. Davis, D. A.; Samocha. T. M.; Bullis, R.; Patnaik, S.; Browdy, C. L.; Stokes, A. D. and Atwood, H. L. (2004). Practical Diets for Litopenaeusvannamei (Boone, 1931): Working Towards Organic and/or All Plant Production Diets. Simposium Internacional de Nutrición Acuícola, 202-214.

9. Hill, B. J. (1979). Biology of the crab Scylla serrata (Forskal) in the St Lucia system. Transactions of the Royal Society of South Africa.44 (1): 55-62.

10.Holme, M. H.; Zeng, C. and Southgate, P. C. (2009). A review of recent progress toward development of a formulated microbound diet for mud crab, larvae and their nutritional requirements. Aquaculture, 286 (3): 164-175.

11.Nguyen, N. T. B.; Chim, L.; Lemaire, P. and Wantiez, L. (2014). Feed intake, molt frequency, tissue growth, feed efficiency and energy budget during a molt cycle of mud crab juveniles, Scylla serrata (Forskal, 1775), fed on different practical diets with graded levels of soy protein concentrate as main source of protein. Aquaculture, 434: 499-509.

12.Quinitio, E. T. and Lwin, M. M. N. (2009). Soft-shell Crab Farming Manual. SEAFDEC Aquaculture Department.

13.Sheen, S. S. (2000). Dietary cholesterol requirement of juvenile mud crab Scylla serrata. Aquaculture, 189 (3-4): 277-285.

14.Suprayudi, M. A.; Takeuchi, T. and Hamasaki, K. (2004). Essential fatty acids for larval mud crab, Scylla serrata: Implications of lack of the ability to bio-convert C18 unsaturated fatty acids to highly unsaturated fatty acids. Aquaculture, 231: 403-416.

15.Truong, P. H. (2008). Nutrition and feeding behaviour in two species of mud crabs Scylla Serrata and Scylla paramamosain (Doctoral dissertation, Queensland University of Technology)

16.Truong, P. H.; Anderson, A. J.; Mather, P. B.; Paterson, B. D. and Richardson, N. A. (2009). Effects of selected feed meals and starches on diet digestibility in the mud crab, Scyllaserrata. Aquaculture Research, 39: 1778-1786.

17.Tuan, V. A.; Anderson, A.; Luong-van, J.; Shelley, C. and Allan, G. (2006). Apparent digestibility of some nutrient sources by juvenile mud crab, Scylla serrata (Forskål 1775). Aquaculture Research, 37: 359 -365. 